\title{
Kelimpahan dan Similaritas Gastropoda di Perairan Pantai Melasti dan Segara Samuh, Badung, Bali
}

\author{
Gusti Ayu Manik Pradnyani a*, I Wayan Arthana a, Ayu Putu Wiweka Krisna Dewi ${ }^{a}$ \\ a Program Studi Manajemen SumberdayaPerairan, Fakultas Kelautan dan Perikanan, Universitas Udayana, Bukit Jimbaran, Bali-Indonesia \\ * Penulis koresponden. Tel.: +62-857-928-377-02 \\ Alamat e-mail: pradnyanimanik@gmail.com
}

Diterima (received) 31 Juni 2018; disetujui (accepted) 25 Agustus 2018

\begin{abstract}
(Melasti and Segara Samuh beach are located in Badung Regency. Melasti beach (station 1) has a water activity only used for swimming. Meanwhile, Segara Samuh beach (station 2) has been utilized for tourism, such as water sport, and fishing. The development of tourism in both stations is feared to affect the abundance of living biota existence in it. This study aims to identify the difference morphological characteristic and the abundance of gastropods, as well as the similarity between points by type of gastropods. This research has been conducted on February-March 2018. This research also used descriptive quantitative method. It has been found that there were 34 species in two stations that have not much different morphological characteristic and there were 25 different spesies in two stations . Station 1 has value of gastropod abundance which was on $66,8 \mathrm{ind} / \mathrm{m}^{2}$, while station 2 was only $36 \mathrm{ind} / \mathrm{m}^{2}$. In general, the high relation and shells diameter have positive values with the highest $R^{2}$ is 0,99 . A high value of similarity was found on 6 points as the result to the abundance of Conus lividus existence at point 4 and 5 with 0,48 as the highest result of negative correlation analysis. The measurement of water quality parameter at station 1 has resulted as follow; $\mathrm{pH} 7,7-$ 7,8, DO 5,3-5,6 mg/L, salinity 30,3-30,9 ppt, and temperature $28-28,1^{\circ} \mathrm{C}$. Meanwhile at station 2, it was resulted with $\mathrm{pH} 7,7$, DO 5,3-5,4 mg/L, salinity 30-30,8 ppt, and temperature $29,6-30{ }^{\circ} \mathrm{C}$. Water condition in two stations were still within the range of seawater quality standards for marine life.
\end{abstract}

Keywords: Melasti Beach; Segara Samuh Beach; Gastropods; Abundance; Water Quality

\begin{abstract}
Abstrak
Pantai Melasti dan Segara Samuh terletak di Kabupaten Badung. Pantai Melasti (stasiun 1) memiliki aktivitas perairan yang hanya digunakan untuk berenang, sedangkan Pantai Segara Samuh (stasiun 2) telah dimanfaatkan untuk wisata, seperti water sport dan penangkapan biota laut. Pengembangan pariwisata di dua stasiun tersebut dikawatirkan dapat mempengaruhi kelimpahan biota yang hidup di dalamnya. Penelitian ini bertujuan untuk mengetahui perbedaan karakteristik morfologi dan perbedaan kelimpahan gastropoda, serta mengetahui kedekatan antar titik berdasarkan jenis gastropoda. Penelitian ini telah dilaksanakan pada bulan Februari hingga Maret 2018. Metode yang digunakan adalah metode deskriptif kuantitatif. Ditemukan sebanyak 34 spesies di dua stasiun yang memiliki karakteristik morfologi yang tidak jauh berbeda dan terdapat 25 spesies yang berbeda di dua stasiun. Stasiun 1 memiliki nilai kelimpahan total gastropoda yaitu $66,8 \mathrm{ind} / \mathrm{m}^{2}$, sedangkan stasiun 2 hanya $36 \mathrm{ind} / \mathrm{m}^{2}$. Hubungan tinggi dan diameter cangkang secara umum memiliki nilai positif dengan nilai $\mathrm{R}^{2}$ tertinggi 0,99 . Nilai similarity yang tinggi terdapat pada 6 titik karena keberadaan Conus lividus yang melimpah di titik 4 dan 5 dengan hasil analisis korelasi negatif tertinggi yaitu 0,48. Hasil pengukuran parameter kulitas air di stasiun 1, yaitu nilai pH 7,7-7,8, DO 5,3-5,6 $\mathrm{mg} / \mathrm{L}$, salinitas 30,3-30,9 ppt, dan suhu 28-28, ${ }^{\circ} \mathrm{C}$, sedangkan stasiun 2, yaitu pH 7,7, DO 5,3-5,4 mg/L, salinitas 30-30,8 ppt, dan suhu $29,6-30^{\circ} \mathrm{C}$. Kondisi perairan di dua stasiun masih berada dalam kisaran baku mutu air laut bagi kehidupan biota laut.
\end{abstract}

Kata Kunci: Pantai Melasti; Pantai Segara Samuh; Gastropoda; Kelimpahan; Kualitas Air 


\section{Pendahuluan}

Pantai Melasti dan Pantai Segara Samuh merupakan pantai yang terletak di sebelah selatan Pulau Bali. Kedua pantai tersebut memiliki aktivitas wisata pantai yang berbeda dan dapat mengakibatkan adanya perbedaan organisme yang hidup di dalamnya. Secara kasat mata, daerah pesisir Pantai Melasti memiliki kondisi perairan pantai yang dapat dikatakan lebih baik dari Pantai Segara Samuh karena hanya digunakan untuk berenang dan belum terdapat akitvitas seperti water sport. Perairan Pantai Segara Samuh merupakan daerah yang telah mengalami eksploitasi dikarenakan kawasan tersebut telah dimanfaatkan untuk berbagai aktivitas, yaitu water sport dan penangkapan biota laut.

Adanya perubahan terhadap salah satu komponen dalam perairan maka pengaruhnya akan terlihat pada keragaman dan kelimpahan biota yang hidup di dalamnya. Pengkajian kualitas perairan dapat dilakukan dengan berbagai cara, yaitu melalui analisis fisika dan kimia air serta analisis biologi. Analisis biologi khususnya struktur komunitas hewan bentos dapat memberikan gambaran yang jelas mengenai kondisi perairan. Salah satu komunitas bentos yang dapat digunakan sebagai indikator perairan adalah gastropoda. Sastrawijaya (2009) mengatakan bahwa gastropoda dapat dijadikan sebagai indikator biologis dalam pencemaran perairan dan baik digunakan sebagai petunjuk kualitas lingkungan, karena selalu kontak dengan limbah yang masuk ke habitatnya. Gastropoda memiliki kepekaan terhadap perubahan lingkungan dan dikategorikan sebagai kelompok organisme fakultatif yang dapat bertahan pada kisaran perubahan lingkungan yang tidak terlalu lebar.

Hasil penelitian Rahmasari (2015) di Sungai Kreo Kota semarang, didapatkan bahwa indeks kelimpahan gastropoda rendah ditemukan pada daerah yang menjadi tujuan wisata, dekat pemukiman penduduk, dan tempat pembuangan akhir (TPA). Berdasarkan hasil penelitian Ayu et al. (2015) di Pantai Selatan Kabupaten Pamekasan, Madura ditemukan nilai gastropoda tertinggi terdapat pada kawasan yang bukan dijadikan daerah penangkapan yang ideal bagi nelayan dan terdapat sedikit aktivitas manusia yang mempengaruhi kehidupan gastropoda sehingga pada kawasan ini masih terjaga dengan baik.
Berdasarkan fakta yang ada di lapangan serta penjelasan dari beberapa literatur di atas oleh karena itu, maka perlu dilakukan penelitian tentang perbandingan kelimpahan gastropoda di pesisir Pantai Melasti dan Pantai Segara Samuh, sehingga dapat memberikan gambaran yang lebih jelas tentang kondisi lingkungan di perairan Pantai Melasti dan Pantai Segara Samuh, Badung, Bali.

Tujuan dari penelitian ini yaitu untuk mengetahui perbedaan karakteristik morfologi gastropoda dan untuk mengetahui perbedaan kelimpahan gastropoda, serta mengetahui kedekatan antar titik dari dua pantai berdasarkan jenis gastropoda di Pantai Melasti dan Pantai Segara Samuh.

\section{Metode Penelitian}

\subsection{Waktu dan Lokasi Penelitian}

Penelitian ini dilaksanakan pada Bulan Februari sampai Maret 2018 di dua pantai, yaitu Pantai Melasti dan Pantai Segara Samuh, Badung, Bali (Gambar 1 dan Gambar 2).

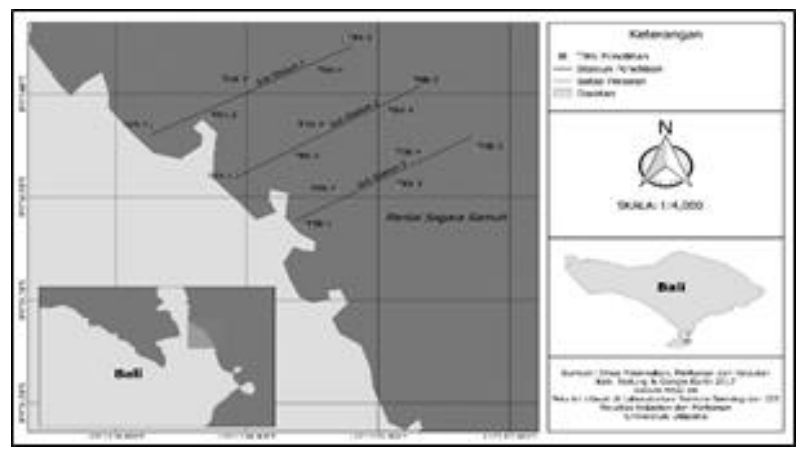

Gambar 1. Peta Lokasi Penelitian Pantai Melasti Keterangan gambar:

1. Sub stasiun 1 Pantai Melasti, terletak dekat dengan anjungan yang biasanya digunakan untuk upacara melasti.

2. Sub stasiun 2 Pantai Melasti, terletak di bagian tengah yang sering dijadikan sebagai tempat berenang dan wisata pantai.

3. Sub stasiun 3 Pantai Melasti, terletak pada bagian sebelah barat pintu masuk pantai dan terdapat saluran limbah dari hotel yang terletak dekat pantai. 


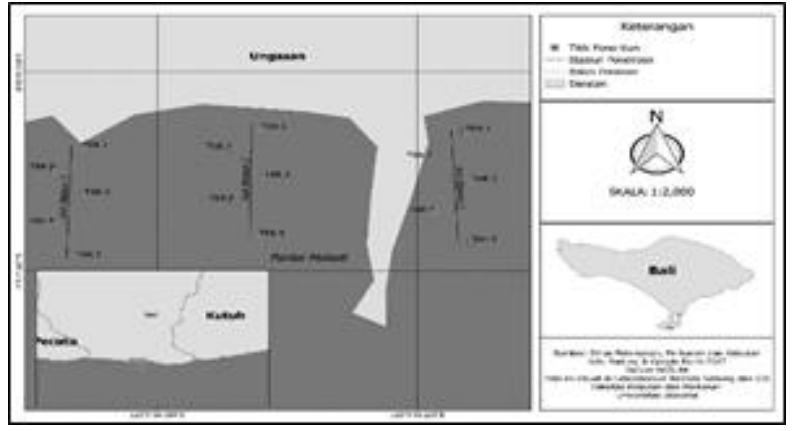

Gambar 2. Peta Lokasi Penelitian Pantai Segara Samuh Keterangan gambar:

1. Sub stasiun 1 Pantai Segara Samuh, terletak pada kawasan yang padat dengan wisata air atau water sport dan tempat berlabuhnya kapal.

2. Sub stasiun 2 Pantai Segara Samuh, terletak pada kawasan pantai yang hanya digunakan sebagai tempat berenang dan merupakan kawasan padang lamun.

3. Sub stasiun 3 Pantai Segara Samuh, terletak pada bagian selatan yang digunakan sebagai tempat memancing

\subsection{Teknik Pengambilan Data}

Pengambilan data dilakukan dengan menggunakan metode observasi langsung. Sampel gastropoda diambil dengan menggunakan transek berukuran 1 x $1 \mathrm{~m}$, kemudian pengambilan sampel dilakukan dengan menggunakan cetok yang kemudian disaring. Sampel yang didapat dimasukkan ke dalam toples plastik dan diberikan alkohol $70 \%$ hingga seluruh bagian tubuh gastropoda terendam. Sampel gastropoda diambil pada masing-masing titik kearah tengah hingga mendekati tubir dengan jarak antar titik $25 \mathrm{~m}$. Sampel yang didapat kemudian diidentifikasi menggunakan buku identifikasi (Carpenter dan Volker, 1998). Pengukuran parameter kualitas air dilakukan secara insitu pada perairan setiap melakukan pengambilan sampel gastropoda. Parameter perairan yang diukur meliputi parameter fisika \{suhu (Lutron, PH-222 Meter)\} dan kimia $\{\mathrm{pH}$ (Lutron, $\mathrm{PH}-222$ Meter), DO (Lutron, DO-5509), dan salinitas (Atago MasterS/MillM(Cat No 2493))\}.

\subsection{Analisis Data}

\subsubsection{Kelimpahan Gastropoda}

Kelimpahan individu gastropoda mengacu pada rumus kelimpahan menurut Fahrul (2007) yaitu:
$K i=\frac{N i}{A}$

dimana $K i$ adalah kelimpahan jenis (ind $\left./ \mathrm{m}^{2}\right) ; N i$ adalah jumlah spesies ke-i (ind); dan $A$ adalah luas area pengamatan $\left(\mathrm{m}^{2}\right)$.

\subsubsection{Indeks Kesamaan Bray-Curtis}

Indeks Kesamaan Bray-Curtis digunakan untuk melihat kesamaan antar stasiun berdasarkan parameter penelitian. Rumus indeks kesamaan Bray-Curtis (Bray and Curtis 1975 dalam Somerfield 2008), yaitu:

$S_{\mathrm{jk}}=100\left(1-\frac{\Sigma|Y i j-Y i k|}{\Sigma(Y i j+Y i k)}\right)$

dimana Sjk adalah indeks kesamaan antara contoh j dan k dalam persen; Yij adalah jumlah spesies ke I dalam kolom j; dan Yik adalah jumlah spesies ke I dalam kolom $\mathrm{k}$.

\subsubsection{Metode Korelasi}

Analisis korelasi adalah suatu cara atau metode untuk mengetahui ada tidaknya hubungan linear antar variabel. Apabila terdapat hubungan maka perubahan-perubahan yang terjadi pada salah satu variabel $(X)$ akan mengakibatkan terjadinya perubahan pada variabel lainnya $(\mathrm{Y})$. Hubungan antar variabel ada 4, yaitu korelasi positif, korelasi negatif, tidak ada korelasi, dan korelasi sempurna (Fraenkel and Wallen, 2008).

\section{Hasil dan Pembahasan}

\subsection{Karakteristik Morfologi Gastropoda}

Karakteristik morfologi gastropoda di Pantai Melasti dan Pantai Segara Samuh dilihat dari identifikasi jenis gastropoda, kondisi habitat, serta ukuran tinggi dan diameter cangkang gastropoda.

3.1.1 Karakteristik Morfologi Gastropoda di Pantai Melasti

Spesies gastropoda yang ditemukan di Pantai Melasti terdiri dari 29 spesies. Dari 29 spesies tersebut terdapat 11 famili, yaitu Nassariidae, Conidae, Pisaniidae, Cerithiidae, Mitridae, Muricidae, Columbellidae, Ocenebrinae, Cypraeidae, Architectonicidae, dan Turbinidae yang memiliki ciri morfologi (bentuk cangkang, corak cangkang, dan ukuran tinggi dan diameter 
cangkang) yang berbeda. Secara umum dari 11 famili tersebut memiliki bentuk cangkang oval dengan bagian ujung cangkang runcing, kecuali pada famili Conidae yang memiliki cangkang berbentuk kerucut. Ukuran tinggi dan diameter cangkang gastropoda secara umum tergolong spesies dewasa, terdapat beberapa famili yang memiliki ukuran cangkang besar, yaitu famili Conidae, Muricidae, dan Turbinidae dengan tinggi cangkang mencapai $4 \mathrm{~cm}$ dan diameter cangkang mencapai $3,5 \mathrm{~cm}$.

3.1.2 Karekteristik Gastropoda di Pantai Segara Samuh

Spesies gastropoda yang ditemukan di Pantai Segara Samuh terdiri dari 13 spesies. Dari 13 spesies tersebut terdapat 11 famili, yaitu Nassariidae, Conidae, Pisaniidae, Muricidae, Teribidae, Olividae, Columbellidae, Cypraeidae, Ovulidae, Neritidae dan Cerithiidae yang memiliki ciri morfologi (bentuk cangkang, corak cangkang, dan ukuran tinggi dan diameter cangkang) yang berbeda. Secara umum dari 11 famili tersebut memiliki bentuk cangkang oval dengan bagian ujung cangkang runcing, kecuali pada famili Conidae yang memiliki cangkang berbentuk kerucut. Ukuran tinggi dan diameter cangkang gastropoda secara umum tergolong spesies dewasa, terdapat dua famili yang memiliki ukuran cangkang besar, yaitu famili Olividae dan Ovulidae dengan tinggi cangkang mencapai $5 \mathrm{~cm}$ dan diameter cangkang mencapai $2,8 \mathrm{~cm}$.

\subsection{Komposisi Jenis Gastropoda}

Berdasarkan hasil identifikasi didapatkan sebanyak 34 spesies gastropoda di dua pantai. Jumlah dan jenis gastropoda yang ditemukan di Pantai Melasti memiliki komposisi jenis yang lebih banyak, yaitu sebanyak 29 spesies dibandingkan dengan komposisi jenis gastropoda di pantai segara samuh hanya 13 spesies, hal tersebut diduga karena pantai segara samuh memiliki lebih banyak aktivitas pantai, sehingga dapat mempengaruhi kehidupan gastropoda. Berdasarkan pernyataan Ayu et al. (2015), bahwa nilai gastropoda tertinggi terdapat pada kawasan yang bukan dijadikan daerah penangkapan yang ideal bagi nelayan dan terdapat sedikit aktivitas manusia yang mempengaruhi kehidupan gastropoda.

Komposisi jumlah dan jenis gastropoda tertinggi yang ditemukan di dua pantai merupakan spesies yang sama yaitu Pyrene testudinaria. Ditemukannya spesies yang sama, karena kedua pantai memiliki substrat berkarang dan berpasir serta terdapat padang lamun yang merupakan habitat pendukung kehidupan gastropoda. Menurut Nur (2011), Pyrene testudinaria hidup pada perairan dangkal dengan kedalaman kurang lebih $1 \mathrm{~m}$, biasanya spesies ini banyak ditemukan pada karang yang ditumbuhi alga dan menempel pada daun lamun.

\subsection{Kelimpahan Gastropoda}

Berdasarkan analisa data didapatkan bahwa spesies gastropoda yang ditemukan di Pantai Melasti sebanyak 29 spesies dan kelimpahan total yaitu 66,8 individu $/ \mathrm{m}^{2}$. Sedangkan spesies gastropoda yang ditemukan di Pantai Segara Samuh lebih sedikit yaitu, 13 spesies dan kelimpahan total jenis gastropoda 36,4

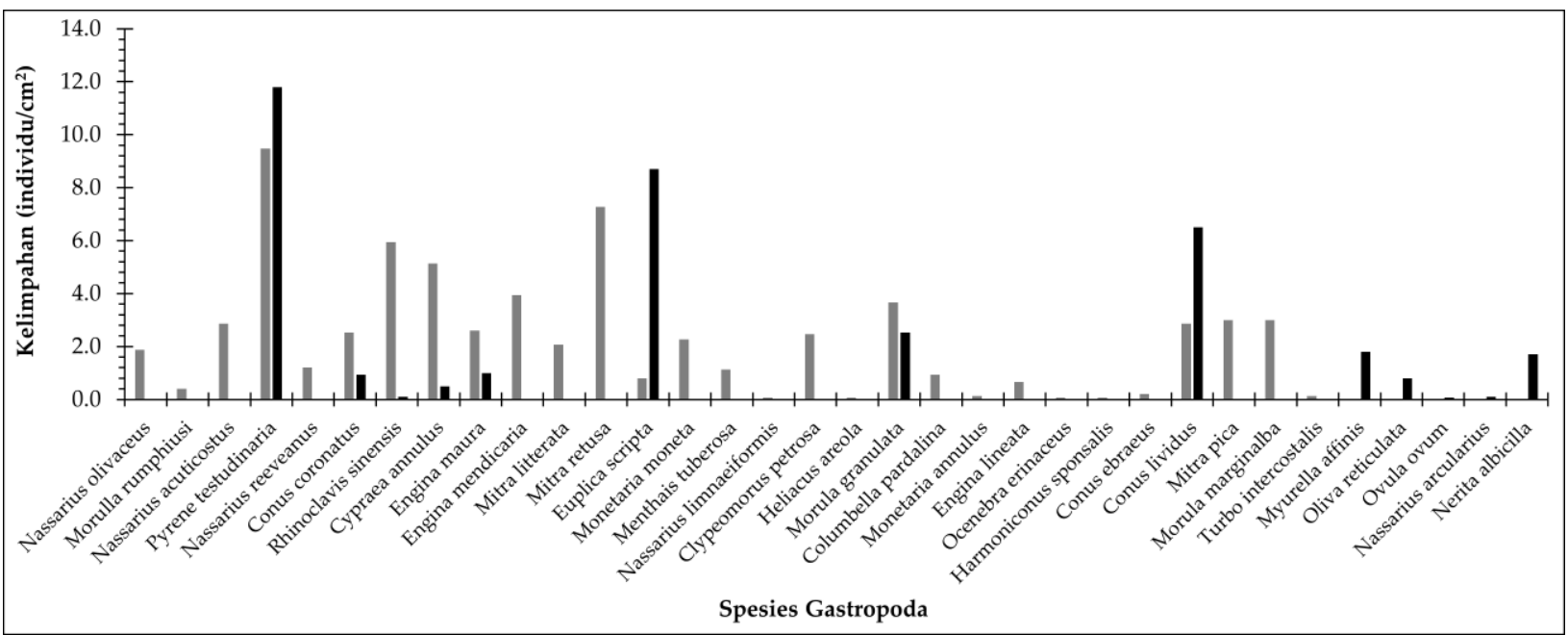

Gambar 3. Kelimpahan Gastropoda di Pantai Melasti ( $\square$ ) dan Pantai Segara Samuh 
individu $/ \mathrm{m}^{2}$ (Gambar 3). Hal tersebut diduga karena Pantai Segara Samuh memiliki substrat berpasir yang menyebabkan gastropoda sulit untuk berlindung dari arus. Septiana (2017), mengatakan bahwa tipe substrat berpasir kurang mendukung untuk kehidupan gastropoda karena substrat berpasir tidak menyediakan tempat untuk melekatkan tubuhnya.

Nilai kelimpahan jenis gastropoda di dua pantai yang paling tinggi terdapat pada spesies yang sama yaitu Pyrene testudinaria sebanyak 9,4 individu $/ \mathrm{m}^{2}$ (Pantai Melasti) dan 11,8 individu $/ \mathrm{m}^{2}$ (Pantai Segara Samuh). Nilai kelimpahan Pyrene testudinaria di Pantai Segara Samuh lebih tinggi dibandingkan dengan di Pantai Melasti, hal tersebut disebabkan karena spesies Pyrene testudinaria mendomonasi di Pantai Segara Samuh dan merupakan spesies yang dapat melekat pada daun lamun, sehingga nilai kelimpahannya lebih tinggi.

3.4 Kelimpahan Gastropoda per Sub Stasiun dari Dua Pantai

Kelimpahan jenis gastropoda pada masingmasing sub stasiun dari dua pantai didapatkan nilai kelimpahan yang beragam. Kelimpahan jenis gastropoda di Pantai Melasti berkisar 0,2-16,8 individu $/ \mathrm{m}^{2}$. Kelimpahan di sub stasiun 1 yaitu $63,4 \mathrm{individu} / \mathrm{m}^{2}$, kelimpahan sub stasiun 2 yaitu 87 individu $/ \mathrm{m}^{2}$, dan kelimpahan sub stasiun 3 yaitu 50,2 individu/m² (Gambar 4). Kelimpahan jenis gastropoda tertinggi pada masing-masing sub (Saripantung, 2013).

Kelimpahan tertinggi pada sub stasiun 2 yaitu spesies Pyrene testudinaria sebanyak 16,8 individu $/ \mathrm{m}^{2}$. Hal tersebut karena substrat di sub stasiun 2 tersebut berkarang dan banyak
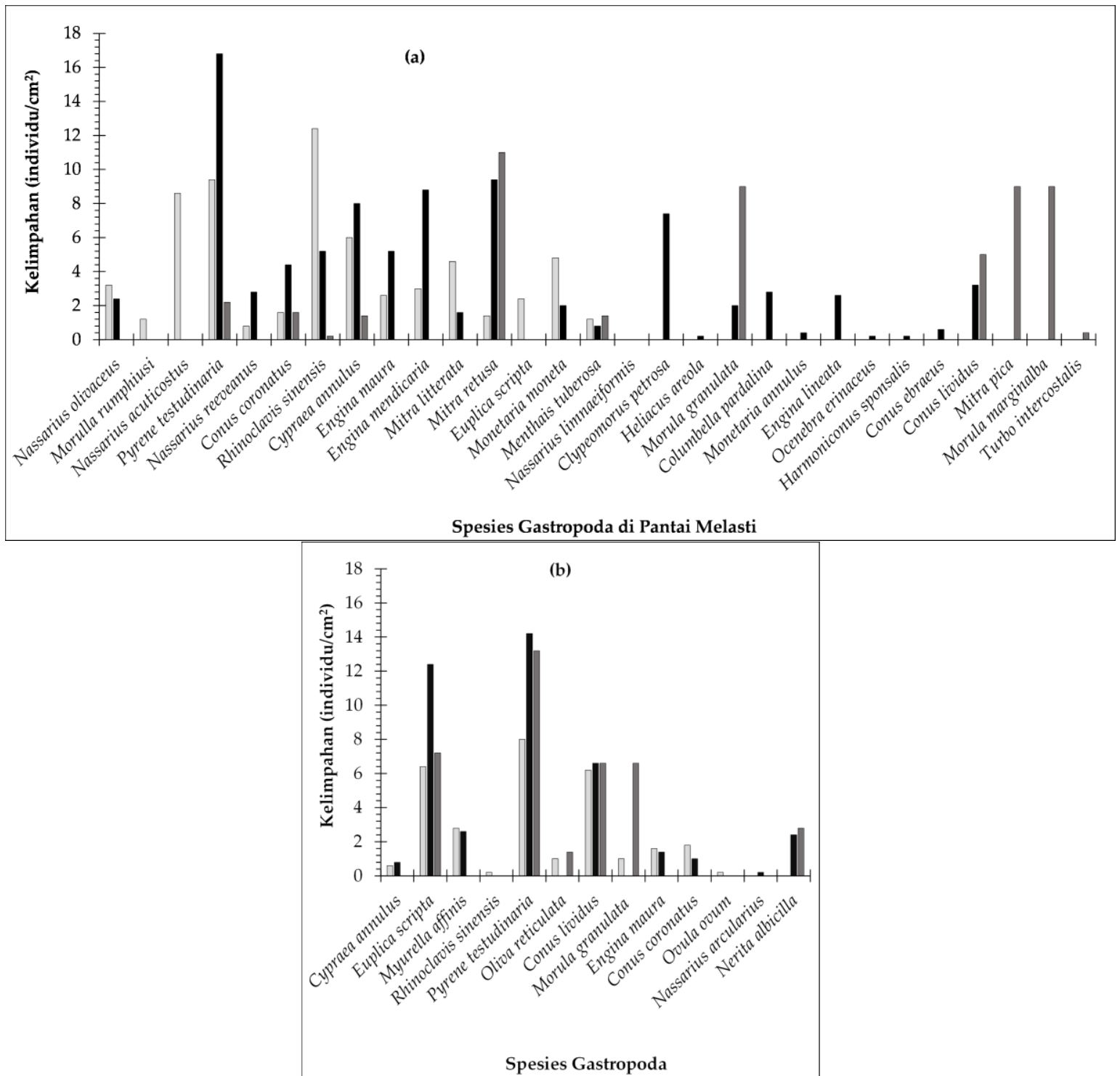

Gambar 4. Kelimpahan Gastropoda per Sub Stasiun dari Semua Stasiun 
ditumbuhi alga, menurut pernyataan Hendrik (2016), genus Pyrene dan Columbella memangsa rumput laut atau makro alga yang menempel pada karang atau pada substrat keras lainnya. Kelimpahan tertinggi pada sub stasiun 3 yaitu Mitra retusa sebanyak 11 individu $/ \mathrm{m}^{2}$. Hal tersebut diduga karena di sub stasiun 3 terdapat masukan limbah dari aktivitas manusia dan Mitra retusa merupakan spesies yang memiliki kemampuan beradaptasi yang lebih terhadap perubahan lingkungan. Famili Mitridae merupakan kelompok bentos yang sangat tolerir atau memiliki ketahanan tubuh yang cukup tinggi sehingga mampu hidup di kondisi perairan tercemar sekalipun (Arief, 2003).

Kelimpahan jenis gastropoda di Pantai Segara Samuh bekisar 0,2-13,2 individu/m2. Kelimpahan di sub stasiun 1 yaitu 29,8 individu/m2, kelimpahan sub stasiun 2 yaitu 41,6 individu/m2, dan kelimpahan sub stasiun 3 yaitu 37,8 individu/m2 (Gambar 4). Kelimpahan tertinggi pada masing-masing sub stasiun di stasiun 2 terdapat pada spesies yang sama, yaitu Pyrene testudinaria, dengan nilai kelimpahan di sub stasiun 1 sebanyak 8 individu/m2, sub stasiun 2 sebanyak 14,2 individu/m2, dan sub stasiun 3 sebanyak 13,2 individu/m2. Pyrene testudinaria melimpah pada 3 sub stasiun diduga karena ketiga sub stasiun di Pantai Segara Samuh memiliki substrat perairan yang sama yaitu berpasir dan terdapat padang lamun yang dapat dijadikan sebagai tempat berlindung dan mencari makan. Menurut Histalessy et al. (2015), Pyrene testudinaria merupakan spesies yang toleran terhadap kondisi suatu perairan dan padang lamun juga merupakan habitat yang baik bagi spesies tersebut untuk mencari makan dan berlindung dari arus dan predator, sehingga pada padang lamun banyak ditemukan gastropoda jenis Pyrene testudinaria.

\subsection{Hubungan Tinggi dan Diameter Cangkang}

Hasil analisis korelasi di Pantai Melasti yang memiliki nilai $\mathrm{R}^{2}$ lebih tinggi dibandingkan dengan spesies yang lainnya ada 4 spesies, yaitu Euplica scripta, Nassarius reeveanus, Pyrene testudinaria, dan Cypraea annulus yang memiliki nilai $\mathrm{R}^{2}$ sebesar 0,99 (Gambar 5). Sedangkan analisis korelasi pada stasiun 2 yang memiliki nilai $\mathrm{R}^{2}$ tertinggi, yaitu Cypraea annulus dengan nilai $\mathrm{R}^{2}$ sebesar 0,99 (Gambar 5). Hubungan tinggi dan diameter cangkang tersebut memiliki nilai positif atau berbanding lurus, dengan nilai R2 mendekati 1 berarti hubungan tinggi dan diameter cangkang pada spesies tersebut sangat kuat.

\subsection{Indeks Kesamaan Bray-Curtis}
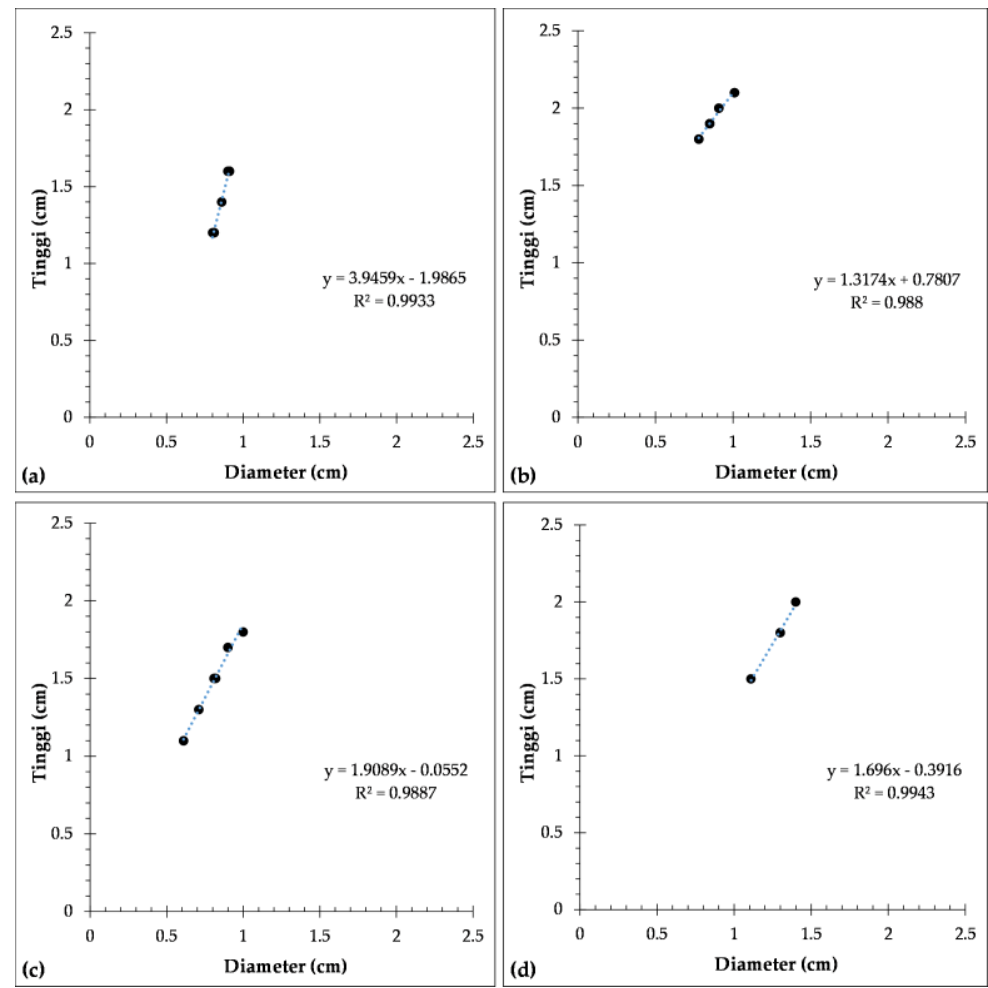

Gambar 5. Hubungan antara tinggi dan diameter cangkang gastropoda berkelimpahan tertinggi di semua stasiun; Euplica scripta (a), Nassarius reeveanus (b), Pyerene testudinaria (c), dan Cypraea annulus 
Hasil topologi dendogram (Gambar 6) menunjukkan bahwa nilai similarity yang lebih tinggi dibandingkan dengan yang lainnya terdapat antara stasiun 1 sub stasiun 2 titik 5 (125, Gambar 6) dengan stasiun 2 sub stasiun 1 titik 4 (214, Gambar 6) sebesar 0,9230 (92,30\%), stasiun $1 \mathrm{sub}$ stasiun 3 titik 5 (135, Gambar 6) dengan stasiun 2 sub stasiun 2 titik 5 (225, Gambar 6) sebesar 0,9333 (93,33\%), dan stasiun 1 sub stasiun 2 titik 5 (125, Gambar 6) dengan stasiun 2 sub stasiun 1 titik 4 (214, Gambar 6) sebesar 0,8888 (88,88\%).

karena terdapat kesamaan spesies yang memiliki nilai kelimpahan tertinggi diantara titik 4 dan titik 5 yaitu Conus lividus berkisar antara 1-21 individu $/ \mathrm{m}^{2}$. Melimpahnya Conus lividus disebabkan oleh kesamaan substrat perairan yaitu berupa pecahan karang. Mengacu pada pernyataan Mudjiono (2009), bahwa famili Conidae termasuk bentos yang memiliki kemamampu melekat sangat kuat sehingga mampu bertahan dari arus yang kuat. Selain itu menurut Nugroho et al. (2012), bahwa famili Conidae merupakan hewan pemangsa yang mengkonsumsi hewan lain sebagai makanannya terdiri dari jenis-jenis avertebrata lain seperti cacing, ikan-ikan kecil dan moluska lain. Sehingga Conus lividus mampu bertahan pada substrat pecahan karang yang jarang ditumbuhi alga.

Keberadaan Conus lividus yang melimpah di titik 4 dan titik 5 didukung dengan hasil analisis korelasi jenis gastropodayang menunjukkan gastropoda tersebut memiliki nilai korelasi negatif tertinggi yaitu 0,48 . Nilai korelasi negatif pada Conus lividus diindikasikan karena gastropoda jenis ini memiliki jumlah yang melimpah pada titik tertentu yaitu titik 4 dan titik 5 yang memiliki substrat berupa pecahan karang sedangkan pada titik pengamatan lainnya yang memiliki substrat selain berupa pecahan karang keberadaanya kurang melimpah bahkan tidak ada sesuai dengan perhitungan kelimpahan Conus lividus di setiap titik pengamatan.

\subsection{Parameter Fisika dan Kimia}

Berdasarkan nilai kelimpahan jenis moluska di kedua stasiun didukung oleh nilai parameter kualitas air dimana rata-rata nilai oksigen terlarut (DO) di stasiun 1 berkisar 5,3-5,6 mg/L dan nilai Do di stasiun 2 berkisar 5,3-5,4 mg/L, nilai tersebut memiliki perbedaan yang tidak jauh berbeda, Kisaran nilai tersebut masih berada pada kisaran baku mutu untuk biota laut yaitu $>5 \mathrm{mg} / \mathrm{L}$ (Pergub Bali No.16 Tahun 2016). Dengan demikian kondisi DO melebihi kisaran optimal yang ditentukan sehingga layak untuk kehidupan gastropoda. Rata-rata nilai $\mathrm{pH}$ di stasiun 1 berkisar 7,7-7,8, sedangkan di stasiun 2 memiliki nilai yang sama yaitu 7,7, Kisaran nilai tersebut masih berada pada kisaran baku mutu untuk biota laut yaitu 78,5 (Pergub Bali No.16 Tahun 2016). Nilai suhu di stasiun 1 dan stasiun 2 berkisar $28-30^{\circ} \mathrm{C}$. Kisaran nilai tersebut masih berada pada kisaran baku mutu untuk biota laut yaitu $28-30^{\circ} \mathrm{C}$ (Pergub Bali No.16 Tahun 2016).

Nilai salinitas di stasiun 1 berkisar 30,3-30,9 ppt sedangkan nilai salinitas di stasiun 2 berkisar 3030,8 ppt, nilai salinitas tersebut baik bagi kehidupan gastropoda, sesuai dengan pernyataan Metungun (2011), kondisi salinitas yang optimal bagi kehidupan gastropoda berada pada kisaran 25-40 ppt.

\section{Simpulan}

Perairan Pantai Melasti dan Pantai Segara Samuh memiliki 25 spesies gastropoda yang berbeda. Secara morfologi spesies tersebut memiliki bentuk cangkang oval dengan ujung yang runcing. Ukuran cangkang gastropoda yang ditemukan di Pantai Melasti dan Pantai Segara Samuh hampir sama, yang secara umum tergolong spesies dewasa. Pantai Melasti memiliki nilai kelimpahan gastropoda sebesar 66,8 individu/ $\mathrm{m}^{2}$, nilai tersebut lebih tinggi dibandingkan dengan nilai kelimpahan di Pantai Segara Samuh hanya 36,4 individu $/ \mathrm{m}^{2}$. Hubungan tinggi dan diameter cangkang secara umum memiliki nilai positif dengan nilai $\mathrm{R}^{2}$ tertinggi 0,99 . Berdasarkan topologi dendogram menunjukkan bahwa terdapat 6 titik dari 30 titik yang memiliki nilai similaritas yang tinggi $(>90 \%)$ didukung dengan keberadaan Conus lividus yang sama-sama melimpah. Perairan Pantai Melasti dan Pantai Segara Samuh dapat dikatakan baik dan dapat mendukung kehidupan biota laut.

\section{Daftar Pustaka}

Arief, A. M. P. (2003). Hutan Mangrove Fungsi dan Manfaatnya. Yogyakarta, Indonesia: Penerbit Kanisius. Yogyakarta.

Ayu, D. M., Ary, S. M., \& Rivanna, C. R. (2015). Keanekaragaman Gastropoda Sebagai Bioindikator Pencemaran Lindi TPA Jatibarang di Sungai Kreo Kota 
Semarang. Dalam Prosiding Seminar Nasional XII Pendidikan Biologi FKIP UNS 2015, (pp. 468-481).

Cappenberg, H. A. W., \& Panggabean, M. G. (2005). Moluska di Perairan Gugus Pulau Pari, Kepulauan Seribu, Teluk Jakarta. J. Oldi, 37, 69-80

Carpenter, K.E. \& V.H. Niem. (1998). FAO Species Identification Guide for Fishery Purposes (Seaweeds, Corals, Bivalves, and Gastropods). Rome, Italy: Food and Agriculture Organization of The United Nations.

Fachrul, M. F. (2007). Metode Sampling Ekologi. Jakarta, Indonesia: Bumi Aksara.

Fraenkel, J., \& Wallen, N. (2008). How to Design and Evaluate Research in Education. New York, USA: McGraw-Hill Higher Education.

Hendrik, A. W. C. (2016). Moluska di Pulau Kabaena, Muna, dan Buton Sulaawesi Tenggara. Oseanologi dan Limnologi di Indonesia. J. Oldi, 1(2), 61-72.

Hitalessy, R. B., Leksono, A. S., \& Herawati, E. Y. (2015). Struktur Komunitas Dan Asosiasi Gastropoda Dengan Tumbuhan Lamun di Perairan Pesisir Lamongan Jawa Timur. J-PAL, 6(1), 64-73

Metungun, J., Juliana, \& Mariana. Y. B. (2011). Kelimpahan Gastropoda Pada Habitat Lamun di Perairan Teluk Un Maluku Tenggara. Jurnal. Pengembangan Pulau - Pulau Kecil. Skripsi. Tual, Indonesia: Politeknik Perikanan Negeri Tual.

Mudjiono. (2009). Telaah komunitas moluska di rataan terumbu (Reefflat) perairan Kepulauan Natuna Besar, Kabupaten Natuna. Oseanologi dan Limnologi di Indonesia, 35(2), 147-160.

Noersativa, F. N., Sutrisno, A., \& Boedi, H. (2015). Sumberdaya Perikanan Bentos: Terebralia sp. Di Ekosistem Hutan Mangrove (Studi Kasus Di Kawasan Mangrove Desa Bedono, Kec. Sayung, Kab. Demak). Maquares, 4(1), 82-90.

Nugroho, K. D., Chrisna., \& Irwani, A. S. (2012). Struktur Komunitas Gastropoda di Perairan Pesisir Kecamatan Genuk Kota Semarang. Program Studi
Ilmu Kelautan, Fakultas Perikanan dan Ilmu Kelautan, Universitas Diponegoro Kampus Tembalang, Semarang. Journal of Marine Research. 1(1),100-109.

Nur, C. (2011). Inventarisasi Jenis Lamun dan Gastropoda Yang Berasosiasi di Perairan Pulau Karampuang Mamuju. Skripsi. Makasar, Indonesia: Program Studi Ilmu Kelautan Fakultas Kelautan dan Perikanan Universitas Hasanuddin Makasar.

Peraturan Gubernur Bali Nomor 16 Tahun 2016 tentang Balu Mutu Lingkungan Hidup dan Kriteria Baku Kerusakan Lingkungan Hidup. Denpasar, Bali: Pemerintah Propinsi Bali.

Rahmasari, T., Tarzan P., \& Reni A. (2015). Keanekaragaman dan Kelimpahan Gastropoda di Pantai Selatan Kabupaten Pamekasan, Madura. Biosaintifika, 7(1), 48-54.

Retnowati, D. N. (2003). Struktur Komunitas Makrozoobentos dan Beberapa Parameter Fisika Kimia Perairan Situ Rawa Besar, Depok, Jawa Barat. Skripsi. Bogor, Indonesia: Departemen Manajemen Sumberdaya Perairan, Fakultas Perikanan dan Ilmu Kelautan. Institut Pertanian Bogor.

Saripantung, G. L. (2013). Struktur Komunitas Gastropoda di Hamparan Lamun Daerah Intertidal Kelurahan TongkeinaKota Manado. Jurnal Ilmiah Platax, 1(3), 102-108.

Sastrawijaya, A. T. (2009). Pencemaran Lingkungan. Jakarta, Indonesia: Rineka Cipta.

Septiana, I. N. (2017). Keanekaragaman Moluska (Bivalvia Dan Gastropoda) di Pantai Pasir Putih Kabupaten Lampung Selatan. Skripsi. Lampung, Indonesia: Fakultas Tarbiyah dan Keguruan, Universitas Islam Negeri Raden Intan.

Somerfield, P. J. (2008). Identification of the Bray-Curtis similarity index: Comment on Yoshioka (2008). Marine ecology progress series, 372, 303-306. 